\title{
DER THEOLOGISCHEN FAKULTÄT
}

DER PHILIPPS-UNIVERSITATT IN MARBURG

FUR VERLEIHUNG EINES

EHRENDOKTORS DER RELIGIONSWISSENSCHAFT

IN DANKBARKEIT ZUGEEIGNET 
